\title{
Evolution of an Osmosensing Histidine Kinase in Field Strains of Botryotinia fuckeliana (Botrytis cinerea) in Response to Dicarboximide Fungicide Usage
}

\author{
Wei Cui, Ross E. Beever, Stephanie L. Parkes, and Matthew D. Templeton
}

First and fourth authors: Gene Technologies Group, The Horticulture and Food Research Institute of New Zealand Ltd., Private Bag 92 169, Auckland, New Zealand; and second and third authors: Landcare Research, Private Bag 92 170, Auckland, New Zealand. Accepted for publication 24 May 2004.

\section{ABSTRACT}

Cui, W., Beever, R. E., Parkes, S. L., and Templeton, M. D. 2004. Evolution of an osmosensing histidine kinase in field strains of Botryotinia fuckeliana (Botrytis cinerea) in response to dicarboximide fungicide usage. Phytopathology 94:1129-1135.

DNA sequence polymorphisms in the putative two-component histidine protein kinase encoded by the Dafl gene have been identified within a sample of 5 sensitive and 27 dicarboximide-resistant field strains of Botryotinia fuckeliana (anamorph Botrytis cinerea). The gene of 3948 bp is predicted to encode a 1315 -amino acid protein comprising an $\mathrm{N}$-terminal region, an amino acid repeat region, which has been hypothesized to be the binding site for dicarboximide fungicide, and a C-terminal region encompassing kinase and response regulator domains. Two amino acid variants were distinguished among the sensitive strains characterized by alanine (group 1), or threonine (group 2), at position 1259 in the Cterminal region. All resistant strains could be classified into either group 1 or group 2 but, in addition, all showed changes in the second amino acid repeat region. On the basis of the differences in this repeat region, four classes of resistant strains were recognized; class 1 characterized by an isoleucine to serine mutation, class 2 by an isoleucine to asparagine mutation, class 3 by an isoleucine to arginine mutation (all at position 365 ), and class 4 by an isoleucine to serine mutation (position 365) as well as a glutamine to proline mutation (position 369). All classes showed similar low levels of resistance to iprodione and to vinclozolin, except for class 3 and class 4 strains, which show low resistance to iprodione but moderate (class 3 ) or high (class 4) resistance to vinclozolin. The classes as a group did not differ from sensitive strains in osmotic sensitivity measured as mycelial growth response, but some class 1 strains showed an abnormal morphology on osmotically amended medium. The evolution of the amino acid differences is discussed in relation to field observations. It is proposed that class 1 and class 2 strains arose by single mutations within the sensitive population, whereas classes 3 and 4 arose by single mutations within a resistant population.

Additional keywords: evolution of fungicide resistance, osmotic sensitivity, two-component signal transduction.
Managing the risk of resistance is an important aspect of modern fungicide usage $(7,17,23)$ but it is often hampered by limited knowledge of the genetic and biochemical bases of resistance mechanisms, especially in field strains. Dicarboximide fungicides, which include iprodione, procymidone, and vinclozolin, have been widely used for the control of plant-pathogenic fungi including Botryotinia fuckeliana (anamorph Botrytis cinerea) since the late 1970s, resulting in the appearance of fungicide-resistant strains in the field in many parts of the world $(3,10,18$, 19,21,37). Despite numerous studies, the precise mode of action of the dicarboximide fungicides has proven elusive, although a link with an osmoregulatory pathway has now been firmly established $(6,22,25)$. It has long been known that certain osmotically sensitive (os) mutants of Neurospora crassa are also resistant to dicarboximide fungicides. The demonstration that $o s-1$ (also known as nik-1) encodes a putative osmosensing histidine kinase $(1,31)$ provided the stimulus to investigate orthologs of this enzyme in B. fuckeliana.

Corresponding author: R. E. Beever

E-mail address: BeeverR@LandcareResearch.co.nz

* The $\boldsymbol{e}$-Xtra logo stands for "electronic extra" and indicates that the online version contains supplemental material not included in the print edition. Figures 1, 2, and 4 are in color online.

Publication no. P-2004-0805-01R

(C) 2004 The American Phytopathological Society
Genetic analysis of dicarboximide-resistant isolates of $B$. fuckeliana obtained both from the field and by selection on fungicidecontaining media in the laboratory has demonstrated that resistance is usually conferred by a single locus (Dafl) (8), although the existence of a second locus has also been identified in laboratory-induced mutants (9). Laboratory mutants usually show abnormal osmotic sensitivity in addition to various levels of dicarboximide resistance, whereas field strains are usually of relatively low resistance and either show a normal or slightly abnormal osmotic response $(2,3,5,8,9,21,22)$. Analysis of laboratory mutants, and crossing studies with an authentic Dafl strain, has been used to demonstrate that this gene encodes a putative osmosensing histidine kinase orthologous to os- 1 in $N$. crassa $(6,22)$. Dicarboximide resistance in these laboratory mutants is associated with a diverse range of single amino acid (aa) changes in the repeat ("coiled-coil") domain.

Naturally, these studies of laboratory mutants beg the question as to the nature of changes associated with dicarboximide resistance in field strains. Two studies based on partial sequences of the aa repeat region have associated resistance of field strains with aa changes in this region $(22,25)$. However, such studies do not exclude the possibility that aa changes elsewhere in the gene may also be involved in conferring resistance. The present work extends these initial studies by examining the full gene sequence in a wide range of strains and comparing the growth properties of resistant strains in relation to the aa differences found. These findings allow us to make hypotheses about the evolution of resistance in the field. 


\section{MATERIALS AND METHODS}

Strains and growth conditions. The strains used in the study are listed in Table 1. They comprise single conidial isolates derived directly from the field and single ascospore isolates obtained by crossing characterized field isolates in the laboratory. In the context of this paper, both classes of strains are referred to as field strains because the resistance genes present are derived from the field rather than via mutation and selection in the laboratory. Genetic terminology follows Weeds et al. (36). Strains were preserved in long-term storage on silica gel at $4^{\circ} \mathrm{C}(27)$, and working cultures were subcultured on malt-extract agar (MEA; Oxoid, Basingstoke, UK). Cultures for conidial production were grown on petri dishes of MEA for 7 to 14 days at $20^{\circ} \mathrm{C}$ under a 12-h on/12-h off cycle of white fluorescent and long-wave ultraviolet radiation. Liquid cultures for DNA extraction were inoculated with $1 \mathrm{ml}$ of a dense conidial suspension and grown in petri dishes for 3 days at $20^{\circ} \mathrm{C}$ on $10 \mathrm{ml}$ of Vogel's medium N (35) supplemented with sucrose $(1 \%, \mathrm{wt} / \mathrm{vol})$ and yeast extract $(0.5 \%$, $\mathrm{wt} / \mathrm{vol})$. Sexual crosses were conducted as previously described (36).

Growth and fungicide testing. Resistance to dicarboximide and benzimidazole fungicides was routinely tested using the spore test previously described (5) using the following fungicides added as $50 \%$ (wt/wt) wettable powders to MEA: iprodione as
Rovral (Bayer Crop Science NZ, Christchurch, NZ), vinclozolin as Ronilan (BASF NZ, Auckland, NZ), procymidone as Sumisclex (NuFarm NZ, Manurewa, NZ), and carbendazim as Bavistin (BASF NZ). Dicarboximide resistance was further examined using the mycelial plug test (5) with MEA plus iprodione (added at $0.1,0.2,0.5,1,2,5,10$, and $100 \mathrm{mg} /$ liter), MEA plus vinclozolin (added at 1, 10, and $100 \mathrm{mg} /$ liter), and MEA plus procymidone (added at 1, 10, and $100 \mathrm{mg} /$ /iter). Osmotic sensitivity was measured using the mycelial plug test with MEA plus $\mathrm{NaCl}$ (added at 10, 20, 40, and $60 \mathrm{~g} /$ liter), as well as by scoring the colony margin on MEA plus $\mathrm{NaCl}$ ( $40 \mathrm{~g} /$ liter) as "fibrillose" or "dense" (3). Radial growth (three replicates) was measured after 2 days growth at $20^{\circ} \mathrm{C}$. On some fungicide-amended media, sectors of predominantly aerial hyphae grew a few millimeters from the inoculum plug. These were disregarded if they arose from less than half of the plug radius. $\mathrm{EC}_{50}$ values for strain growth on amended MEA media were calculated using the SAS statistics package (SAS Institute, Cary, NC). Resistance factors are defined as the ratio of growth response relative to the mean response of the sensitive strains. Responses of classes of strains were compared by analysis of variance, with the estimate of error based on variation between isolates within a group rather than between individual replicates. Where $F$ tests were found to be significant, means were separated using the least significant difference test $(P=0.05)$.

TABLE 1. Sources of strains of Botryotinia fuckeliana used in this study

\begin{tabular}{|c|c|c|c|c|c|c|}
\hline Strain & ICMP no. ${ }^{x}$ & Type & Source country or parents & Host & Year $^{\mathrm{y}}$ & Resistance class ${ }^{2}$ \\
\hline A1 & 13670 & Ascospore & REB702-1 × REB705-1 & - & 1985 & Sensitive \\
\hline SAS56 & 10934 & Ascospore & Italy & - & $<1988$ & Sensitive \\
\hline SAS405 & 10935 & Ascospore & Italy & - & $<1988$ & 1 \\
\hline REB658-1 & 14114 & Conidial & New Zealand (Auckland) & Kiwifruit & 1982 & Sensitive \\
\hline REB689-1 & 15030 & Conidial & New Zealand (Auckland) & Begonia & 1983 & 1 \\
\hline REB699-1 & 15035 & Conidial & New Zealand (Auckland) & Grape & 1985 & 2 \\
\hline REB702-1 & 14118 & Conidial & New Zealand (Marlborough) & Grape & 1985 & Sensitive \\
\hline REB704-1 & - & Conidial & New Zealand (Waikato) & Grape & 1985 & - \\
\hline REB705-1 & 14119 & Conidial & New Zealand (Waikato) & Grape & 1985 & 1 \\
\hline REB749-8 & 15036 & Ascospore & SAS405 × REB704-1 & - & 1985 & 2 \\
\hline $\begin{array}{l}\text { REB778-56 } \\
\text { (Baudoin BS-26C) }\end{array}$ & 15029 & Conidial & USA (Virginia) & Grape & 1992-93 & Sensitive \\
\hline $\begin{array}{l}\text { REB778-59 } \\
\text { (Baudoin H3) }\end{array}$ & 15034 & Conidial & USA (Virginia) & Grape & 1992-93 & 2 \\
\hline REB909-51 & 15039 & Conidial & New Zealand (Pukekohe) & Grape & 1999 & 4 \\
\hline REB909-52 & - & Conidial & New Zealand (Pukekohe) & Grape & 1999 & - \\
\hline REB909-54 & - & Conidial & New Zealand (Pukekohe) & Grape & 1999 & 4 \\
\hline REB909-56 & - & Conidial & New Zealand (Pukekohe) & Grape & 1999 & 4 \\
\hline REB954-1 & 15040 & Ascospore & REB702-1 × REB909-56 & - & 1999 & 4 \\
\hline REB954-202 & - & Ascospore & REB689-1 × REB909-52 & - & 1999 & 4 \\
\hline REB954-204 & - & Ascospore & REB689-1 × REB909-52 & - & 1999 & 4 \\
\hline $\begin{array}{l}\text { REB962-10 } \\
\text { (VB57 = Katan ME-1) }\end{array}$ & - & Conidial & Israel & Melon & $<1993$ & 1 \\
\hline $\begin{array}{l}\text { REB962-11 } \\
\quad(\text { VB59 = Pappas 5T/87) }\end{array}$ & - & Conidial & Greece & Tomato & $<1993$ & Sensitive \\
\hline $\begin{array}{l}\text { REB962-8 } \\
\text { (V10 = Pezet P.84) }\end{array}$ & - & Conidial & Switzerland & Grape & $<1993$ & 2 \\
\hline $\begin{array}{l}\text { REB962-9 } \\
\text { (V11 = Coley-Smith 6) }\end{array}$ & 15037 & Conidial & England & Lettuce & $<1993$ & 3 \\
\hline REB964-1 & - & Conidial & New Zealand (Pukekohe) & Grape & 2000 & 2 \\
\hline REB964-2 & - & Conidial & New Zealand (Pukekohe) & Grape & 2000 & 1 \\
\hline REB964-3 & 15032 & Conidial & New Zealand (Pukekohe) & Grape & 2000 & 1 \\
\hline REB964-4 & - & Conidial & New Zealand (Pukekohe) & Grape & 2000 & 1 \\
\hline REB965-1 & - & Conidial & New Zealand (Hawkes Bay) & Grape & 2000 & 2 \\
\hline REB965-2 & 15031 & Conidial & New Zealand (Hawkes Bay) & Grape & 2000 & 1 \\
\hline REB965-3 & - & Conidial & New Zealand (Hawkes Bay) & Grape & 2000 & 2 \\
\hline REB965-4 & - & Conidial & New Zealand (Hawkes Bay) & Grape & 2000 & 2 \\
\hline REB966-1 & 15033 & Conidial & New Zealand (Marlborough) & Grape & 2001 & 1 \\
\hline REB966-3 & - & Conidial & New Zealand (Marlborough) & Grape & 2001 & 2 \\
\hline REB966-5 & 15038 & Conidial & New Zealand (Marlborough) & Grape & 2001 & 3 \\
\hline REB966-6 & - & Conidial & New Zealand (Marlborough) & Grape & 2001 & 1 \\
\hline
\end{tabular}

${ }^{\mathrm{x}}$ International Collection of Microorganisms from Plants (ICMP) maintained by Landcare Research.

y Indicates year in which the strains Dafl allele was recovered from the field.

z Strains classified according to predicted amino acids present at positions 365 and 369 in Daf1p (Fig. 1). 
Molecular biological manipulations. All routine molecular biological manipulations were carried out according to standard methods (30). Genomic DNA was prepared using a microscale method (6). The primers Bos1R13 and Bos1R31 (6) were used to amplify the entire Dafl gene from selected strains. Polymerase chain reactions (PCRs) were performed in a total volume of $50 \mu \mathrm{l}$ in a final concentration of $200 \mu \mathrm{M}$ dNTPs (Deoxynucleoside Triphosphate Set, PCR Grade, Roche Molecular Biochemicals, Mannheim, Germany), $300 \mathrm{nM}$ each primer, $50 \mathrm{ng}$ of template DNA, 2.5 units of Expand High Fidelity PCR System enzyme mix (Expand High Fidelity PCR System, Roche Molecular Biochemicals), and $1 \times$ Expand HF buffer with $2.5 \mathrm{mM} \mathrm{MgCl}{ }_{2}$. PCR was carried out with a Techne Genius thermal cycler (Techne, Cambridge, UK) programmed as follows: 2 min at $95^{\circ} \mathrm{C}$ followed by 30 cycles of $30 \mathrm{~s}$ at $94^{\circ} \mathrm{C}, 30 \mathrm{~s}$ at $57^{\circ} \mathrm{C}$, and $4 \mathrm{~min}$ at $68^{\circ} \mathrm{C}$. PCR products were gel-purified from $0.8 \%$ agarose gel using a QIAquick Gel Extraction Kit (Qiagen, Hilden, Germany). The purified DNA fragments were either sequenced directly using customized sequencing primers or cloned into pGEM-T Easy
Vector (Promega, Madison, WI) before sequencing. Samples for sequencing were prepared using an ABI Prism BigDye Terminator version 3.0 Ready Reaction Cycle Sequencing Kit (ABI Applied Biosystems, Foster City, CA) following the manufacturer's instructions, and the DNA sequences were determined using a DNA sequencer (ABI Prism 377, ABI Applied Biosystems). Overlapping sequencing primers were used to provide complete coverage of the gene in both directions (6), and all full sequence determinations were repeated at least once. Sequence assembly and analysis were performed using STADEN (33). Sequence comparisons were carried out using GCG (Genetic Computer Group, Madison, WI).

\section{RESULTS}

Sequence of the Daf1 gene in sensitive field strains. A total of four alleles, two sourced from New Zealand, one from Europe, and one from the United States, were fully sequenced (Fig. 1). Nucleotide differences were detected at five positions, but all are

A

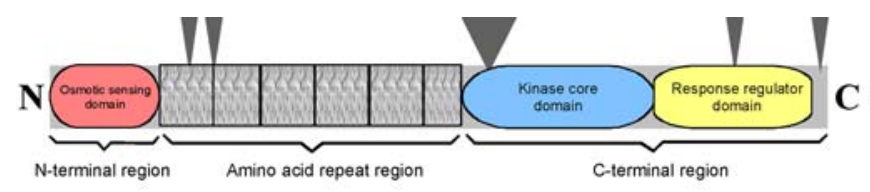

\begin{tabular}{|c|c|c|c|c|c|c|c|c|c|c|c|c|c|c|c|c|c|c|c|c|c|c|c|c|c|c|}
\hline \multirow{3}{*}{$\begin{array}{l}\text { Resistance } \\
\text { classes }\end{array}$} & \multirow{3}{*}{\multicolumn{2}{|c|}{ Group Strains }} & \multicolumn{24}{|c|}{$\begin{array}{l}\text { Polymorphic positions in genomic DNA sequence } \\
\text { (amino acid sequence) }\end{array}$} \\
\hline & & & \multicolumn{5}{|c|}{$\mathrm{N}$ - terminal region } & \multicolumn{6}{|c|}{ Amino acid repeat region } & \multicolumn{13}{|c|}{ C-terminal region } \\
\hline & & & $\stackrel{21}{\pi}$ & $\begin{array}{c}311 \\
(104)\end{array}$ & $\begin{array}{c}396 \\
(132) \\
\end{array}$ & $\begin{array}{r}462 \\
(154) \\
\end{array}$ & $\begin{array}{r}561 \\
(187) \\
\end{array}$ & $\begin{array}{l}1203 \\
(361)\end{array}$ & $\begin{array}{c}1213 / 4 / 5 \\
(305)\end{array}$ & $\begin{array}{l}1226 \\
(309) \\
\end{array}$ & $\begin{array}{l}1347 \\
(409)\end{array}$ & $\begin{array}{r}1305 \\
(410) \\
\end{array}$ & $\begin{array}{l}1743 \\
(541) \\
\end{array}$ & $\begin{array}{c}2388 \\
\text { (ntron3) }\end{array}$ & $\begin{array}{l}2502 \\
\text { (intron } 3)\end{array}$ & $\begin{array}{r}3332 \\
(1003) \\
\end{array}$ & $\begin{array}{r}3464 \\
(1047) \\
\end{array}$ & $\begin{array}{r}3470 \\
(1049) \\
\end{array}$ & $\begin{array}{r}3515 \\
(1064) \\
\end{array}$ & $\begin{array}{r}3643 \\
(1107 \\
\end{array}$ & $\begin{array}{c}3936 \\
(1186) \\
\end{array}$ & $\begin{array}{c}3946 \\
(1190)\end{array}$ & $\begin{array}{r}4045 \\
(1223)\end{array}$ & $\begin{array}{l}4104 \\
(1242) \\
\end{array}$ & $\begin{array}{l}4153 \\
(1259)\end{array}$ & $\begin{array}{l}4316 \\
\text { (intron5) }\end{array}$ \\
\hline \multirow[t]{4}{*}{ Sensitive } & 1 & A1/SAS56 & (A) & $\begin{array}{c}6 \\
\text { (Arg) }\end{array}$ & $\frac{c}{c}$ & $\begin{array}{c}T \\
\text { (sen) }\end{array}$ & (A A & (Gin) & $\begin{array}{l}\text { ATC } \\
\text { (16) }\end{array}$ & (Aln) & $\begin{array}{c}c \\
\text { (val) }\end{array}$ & (A) & $\hat{(A \mid y)}$ & $\begin{array}{l}T \\
(-)\end{array}$ & A & $\begin{array}{c}c \\
\text { (Pro) }\end{array}$ & $\begin{array}{c}G \\
\text { (Glu) }\end{array}$ & $\begin{array}{c} \\
\text { (Lys) }\end{array}$ & A & $\begin{array}{c}c \\
\text { (Ser) }\end{array}$ & ${ }_{(\mathrm{P} r 0)}^{\top}$ & $\begin{array}{c}c \\
\text { (Lou) }\end{array}$ & A & $\frac{G}{G}$ & $\begin{array}{c} \\
\text { (Ala) }\end{array}$ & $\begin{array}{l}c \\
c \\
(-)\end{array}$ \\
\hline & 1 & REB962-11 & & & & & & . & . & $\cdot$ & . & . & . & & & & & & & & & & & & & \\
\hline & 2 & REB658-1 & $\begin{array}{l}T \\
\text { (.) }\end{array}$ & . & $\cdot$ & . & . & . & . & . & . & . & $\begin{array}{l}G \\
\text { (.) }\end{array}$ & . & . & . & . & . & . & . & . & . & . & . & (Thr) & $\stackrel{T}{(-)}$ \\
\hline & 2 & REB778-56 & . & $\cdot$ & $\cdot$ & . & $\begin{array}{l}G \\
\text { (.) }\end{array}$ & . & . & · & $\cdot$ & . & $\begin{array}{l}G \\
\text { (.) }\end{array}$ & . & . & $\cdot$ & . & $\cdot$ & · & $\cdot$ & . & . & $\cdot$ & $\cdot$ & (Thr) & $\begin{array}{c}T \\
(*)\end{array}$ \\
\hline \multirow[t]{8}{*}{ One } & 1 & REB689-1 & . & . & $\cdot$ & . & . & . & $\begin{array}{l}A G C \\
\text { (Ser) }\end{array}$ & . & · & . & · & · & . & · & . & . & . & $\cdot$ & $\cdot$ & . & · & · & . & . \\
\hline & 1 & REB965-2 & . & . & $\cdot$ & . & . & . & $\begin{array}{l}\text { AGC } \\
\text { (Ser) }\end{array}$ & . & . & . & . & . & . & . & . & . & $\cdot$ & $\begin{array}{c}T \\
\text { (Phe) }\end{array}$ & $\begin{array}{l}\mathrm{c} \\
\text { (.) }\end{array}$ & . & $\underset{\text { (Ala) }}{G}$ & (.) & . & . \\
\hline & 1 & $\begin{array}{l}\text { REB962-10/ } \\
964-2 / 964-4\end{array}$ & & & & & & $\begin{array}{c}\mathrm{c} \\
(.)\end{array}$ & $\begin{array}{l}\text { AGC } \\
\text { (Ser) }\end{array}$ & . & . & . & . & & & & & & & & & & & & & \\
\hline & 2 & REB705-1 & . & . & · & . & . & . & $\begin{array}{l}\mathrm{AGC} \\
\text { (Ser) }\end{array}$ & . & · & . & $\begin{array}{l}6 \\
\text { (.). }\end{array}$ & . & . & . & · & . & . & · & . & . & . & $\cdot$ & $\stackrel{\text { A }}{\text { (Thr) }}$ & $\stackrel{T}{\leftrightarrow}$ \\
\hline & 2 & SAS405-1 & . & . & $\cdot$ & . & $\begin{array}{l}G \\
(\cdot)\end{array}$ & . & $\begin{array}{l}\text { AGC } \\
\text { (Ser) }\end{array}$ & . & . & · & $\begin{array}{l}G \\
\text { (.) }\end{array}$ & . & . & . & . & . & . & . & . & . & . & $\cdot$ & $\stackrel{\text { A }}{\text { (Thr) }}$ & $\begin{array}{l}T \\
(-)\end{array}$ \\
\hline & 2 & REB966-1 & . & . & $\begin{array}{l}T \\
\text { (.) }\end{array}$ & . & $\begin{array}{l}G \\
(.)\end{array}$ & . & $\begin{array}{l}A G C \\
\text { (Ser) }\end{array}$ & . & . & . & $\begin{array}{l}G \\
\text { (.) }\end{array}$ & . & . & · & . & . & . & . & . & . & . & $\cdot$ & (Thr) & $\stackrel{T}{T}$ \\
\hline & 2 & REB964-3 & . & · & . & . & . & $\begin{array}{l}\text { c } \\
\text { (.) }\end{array}$ & $\begin{array}{l}\text { AGC } \\
\text { (Ser) }\end{array}$ & . & $\begin{array}{l}T \\
\text { (.) }\end{array}$ & $\begin{array}{l}G \\
\text { (.) }\end{array}$ & . & . & . & · & . & . & $\begin{array}{l}G \\
(\cdot)\end{array}$ & $\cdot$ & . & $\begin{array}{c}\text { (Phe) } \\
\text { (Phe) }\end{array}$ & . & $\cdot$ & $\stackrel{A}{A}$ & $\begin{array}{c}T \\
(-)\end{array}$ \\
\hline & 2 & REB966-6 & & & & & & . & $\begin{array}{l}A G C \\
\text { (Ser) }\end{array}$ & . & . & . & $\begin{array}{l}G \\
\text { (.) }\end{array}$ & & & & & & & & & & & & & \\
\hline \multirow[t]{3}{*}{ Two } & 1 & REB778-59 & . & (GAn) & . & . & . & - & $\begin{array}{l}\text { AAC } \\
\text { (Asn) }\end{array}$ & . & . & . & . & . & . & . & . & . & . & . & . & . & . & . & . & . \\
\hline & 1 & $\begin{array}{l}\text { REB965-3/ } \\
965-4 / 965-1 / \\
964-1 / 966-3 / \\
962-8\end{array}$ & & & & & & . & $\begin{array}{l}\text { AAC } \\
\text { (Asn) }\end{array}$ & . & . & . & . & & & & & & & & & & & & & \\
\hline & 2 & $\begin{array}{l}\text { REB699-1/ } \\
749-8\end{array}$ & . & $\cdot$ & · & $\begin{array}{l}\mathrm{c} \\
\text { (.) }\end{array}$ & · & · & $\begin{array}{l}\text { Aat } \\
\text { (Asn) }\end{array}$ & · & . & . & $\begin{array}{l}G \\
(.)\end{array}$ & $\begin{array}{c}c \\
(\rightarrow)\end{array}$ & $\begin{array}{c}\mathrm{c} \\
(\rightarrow)\end{array}$ & $\begin{array}{l}\mathrm{T} \\
(.)\end{array}$ & $\begin{array}{l}\text { A } \\
(.)\end{array}$ & $\begin{array}{l}\text { A } \\
\text { (.) }\end{array}$ & $\cdot$ & $\cdot$ & . & . & . & $\cdot$ & $\stackrel{A}{A}$ & $\begin{array}{c}T \\
(-)\end{array}$ \\
\hline Three & 1 & $\begin{array}{l}\text { REB962-9/ } \\
966-5\end{array}$ & & & & & & . & $\begin{array}{l}\operatorname{coc} \\
\text { (Arg) }\end{array}$ & . & . & . & . & & & & & & & & & & & & & \\
\hline \multirow[t]{2}{*}{ Four } & 1 & $\begin{array}{l}\text { REB909-51/ } \\
\text { 954-1 }\end{array}$ & . & $\cdot$ & $\cdot$ & $\cdot$ & . & . & $\begin{array}{l}\text { AGC } \\
\text { (Sen) }\end{array}$ & $\begin{array}{c}c \\
\text { (Pro) }\end{array}$ & . & . & . & . & . & . & . & . & . & . & . & . & . & . & . & . \\
\hline & 1 & $\begin{array}{l}\text { REB909-54/ } \\
909-56 / 954-20 \\
954-204\end{array}$ & & & & & & . & $\begin{array}{l}\text { AGC } \\
\text { (Ser) }\end{array}$ & $\underset{\text { (Pro) }}{c}$ & . & . & . & & & & & & & & & & & & & \\
\hline
\end{tabular}

Fig. 1. Diagram of the Botryotinia fuckeliana Dafl coding sequence showing different regions and locations of all variable sites detected in strains examined. A, Diagram of structural region of the osmosensing histidine kinase encoded by Dafl in Botrytis cinerea. The horizontal bar indicates the full-length sequence of predicted Daflp containing 1,315 amino acids (aa). Protein-encoding domains are shown on the bar in boxes. Position of introns is given as inverted triangles above the bar. B, Resistance class allocations are based on the nucleotides at positions 1213 to 1215 and 1226 . The strain groups are defined for fully sequenced strains by the aa polymorphism at position 1259, with alanine (group 1) or threonine (group 2). Fully sequenced alleles are indicated in bold. Where partial sequences only are available, strains are allocated to their group on the basis of the nucleotide present at position 1743 (A for group 1, G for group 2). All positions at which the sequence differs from that of sensitive strains A1 and SAS56 are indicated in bold. 
predicted to be silent except at nucleotide position 4153 (aa position 1259) near the $C$ terminus with two strains (designated group 1) having G, encoding alanine and two strains (designated group 2) having A, encoding threonine. This difference also matched consistently with "silent" nucleotide differences at positions 1743 (A or $\mathrm{G}$ ) in the aa repeat region and $4316(\mathrm{C}$ or $\mathrm{T}$ ) in intron 5. The only other available sequence, accession AF396827 (22) from a French sensitive strain, falls into group 2 . The same aa polymorphism was present in the dicarboximide-resistant alleles sequenced (described below), and we conclude it is widespread and unrelated to dicarboximide resistance. Considering all fully sequenced alleles, both group 1 and group 2 isolates were found in Australasia (New Zealand), Europe (Italy), and North America (Virginia).

Sequence of the Daf1 gene in resistant field strains. The Dafl allele was fully sequenced from a total of 11 strains (Fig. 1). Examination of these sequences demonstrated that five were from aa polymorphism group 1 , and six were from group 2 . In addition, the aa repeat region was sequenced from a further 16 strains. All resistant strains showed differences in the aa repeat region from all of the sensitive strains. On the basis of these aa differences, we recognize four classes of resistant strains. In resistance class 1 strains, the nucleotide at position 1214 is $\mathrm{G}$ rather than $\mathrm{T}$, encoding serine rather than isoleucine at aa position 365 ; in resistance class 2 strains, the nucleotide at position 1214 is A, encoding asparagine at aa position 365 ; in resistance class 3 , the nucleotide at position 1213 is $\mathrm{C}$ rather than $\mathrm{A}$, and at position 1214 is $\mathrm{G}$ rather than $\mathrm{T}$, encoding arginine at aa position 365 ; and in resistance class 4 , the nucleotide at position 1214 is $\mathrm{G}$, encoding serine at aa position 365 , and in addition the nucleotide at position 1226 is $\mathrm{C}$, encoding proline rather than glutamine at aa position 369. As well as these predicted differences, three of the fully sequenced alleles showed additional aa differences elsewhere in the sequence but, because none of these differences were present in more than one resistant strain or in the sensitive strains, we conclude that they are rare polymorphisms unlikely to be related to resistance. Similarly, a number of silent nucleotide level differences were observed between the various strains. Most were restricted to only a few strains, but those at positions 1743 in the aa repeat region and position 4316 in intron 5 were more common. These differences match those used to define the aa polymorphism groups, except for group 2 strain REB964-3, which has an A rather than a $\mathrm{G}$ at position 1743.

Growth characteristics of resistant strains. Selected physiological properties and fungicide responses of the strains examined are provided in Table 2 and illustrated in Figure 2. Considered as groups, none of the resistance classes showed significant differences from the sensitive strain class in radial growth, production of conidia, or production of sclerotia on nonamended media. Sensitive strains showed negligible growth on the dicarboximideamended media, whereas all four classes of field resistant strains showed some growth on the dicarboximide-amended media. Classes 1 and 2 showed similar low-level resistance to vinclozolin and iprodione, with resistance factors for iprodione ranging from 3.8- to 20.2-fold (class 1) and 2.6- to 7.4-fold (class 2). Class 3 strains were slightly more resistant to vinclozolin than classes 1 and 2 but showed similar responses to iprodione (resistance factors 10.2- to 15.1-fold). Class 4 strains formed a distinct group showing relatively high resistance to vinclozolin, with growth on $100 \mathrm{mg} /$ liter greater than $50 \%$ of control, but relatively low resistance to iprodione (resistance factors 9- to 15.8-fold). Class 4 strains have not been characterized previously, and selected strains were crossed to determine the genetic basis of the resistance (Table 3). The high vinclozolin resistance phenotype segregated 1:1 in crosses to a dicarboximide-sensitive strain (crosses 1 and 2) and no dicarboximide-sensitive recombinants were found in 100 progeny of a cross to an authentic Dafl strain (cross 3), indicating that class 4 strains map to this locus. Cross 3 also confirms that Dafl is loosely linked to $M b c 1$ (25\% recombination) as has been established previously (6). Class 4 strain REB954-1 was also found to show high resistance to procymidone $\left(\mathrm{EC}_{50}>100 \mathrm{mg} / \mathrm{liter}\right)$, whereas class 1 strain REB705-1 showed only low-level resistance $\left(\mathrm{EC}_{50}\right.$ between 1 and $\left.10 \mathrm{mg} / \mathrm{liter}\right)$ to this fungicide (data not shown).

TABLE 2. Growth properties of sensitive and dicarboximide-resistant strains of Botryotinia fuckeliana

\begin{tabular}{|c|c|c|c|c|c|c|c|c|}
\hline \multirow{3}{*}{$\begin{array}{l}\text { Resistance } \\
\text { class }^{\mathrm{w}}\end{array}$} & \multirow{3}{*}{$\begin{array}{l}\text { No. of } \\
\text { strains }\end{array}$} & \multirow{3}{*}{$\frac{\begin{array}{c}\text { Radial growth } \\
(\mathrm{mm})\end{array}}{\text { Mean }(\mathrm{SE})}$} & \multirow{3}{*}{$\begin{array}{l}\text { Conidial production } \\
\left(\times 10^{-8} / \text { petri dish }\right)\end{array}$} & \multirow{3}{*}{$\begin{array}{c}\left.\begin{array}{c}\text { Sclerotial production } \\
(\text { number/cm }\end{array}\right)^{2} \\
\text { Mean }(\mathrm{SE})\end{array}$} & \multicolumn{3}{|c|}{ Radial growth on MEA } & \multirow{3}{*}{$\begin{array}{l}\text { Osmotic } \\
\text { response }^{z}\end{array}$} \\
\hline & & & & & $\begin{array}{l}\text { + Vinclozolin } \\
\text { (100 mg/liter) }\end{array}$ & $\begin{array}{l}+ \text { Iprodione }^{\mathrm{x}} \\
\text { (mg/liter) }\end{array}$ & $\begin{array}{l}+\mathrm{NaCl}^{\mathrm{x}} \\
\text { (g/liter) }\end{array}$ & \\
\hline & & & & & $\%$ Growth (SE) & $\mathrm{EC}_{50}{ }^{\mathrm{y}}(\mathrm{SE})$ & $\mathrm{EC}_{50} \mathrm{y}(\mathrm{SE})$ & \\
\hline Sensitive & 5 & $23.3(1.05) \mathrm{a}$ & $0.9(1.23) \mathrm{a}$ & $0.9(1.41) \mathrm{ab}$ & 0.5 (1.09) a & $0.18(1.21) \mathrm{a}$ & $41.8(10.9) \mathrm{ab}$ & $\mathrm{f}$ \\
\hline 1 & 10 & $23.7(1.03) \mathrm{a}$ & $1.4(1.16) \mathrm{a}$ & $1.2(1.27) \mathrm{a}$ & $6.9(1.06) b$ & $1.65(1.14) b c$ & $33.9(10.7) \mathrm{a}$ & $d$ or $f$ \\
\hline 2 & 9 & $23.6(1.03) \mathrm{a}$ & $1.2(1.16) \mathrm{a}$ & $0.5(1.29) \mathrm{ab}$ & $5.6(1.07) b$ & $0.98(1.15) \mathrm{b}$ & $44.8(10.7) b$ & $\mathrm{f}$ \\
\hline 3 & 2 & $23.6(1.07) \mathrm{a}$ & $1.9(1.38) \mathrm{a}$ & $0.3(1.72) \mathrm{ab}$ & $12.1(1.15) \mathrm{c}$ & $2.23(1.35) b c$ & $36.8(11.5) \mathrm{ab}$ & $d$ or $f$ \\
\hline 4 & 6 & $24.9(1.04) \mathrm{a}$ & $1.1(1.21) \mathrm{a}$ & $0.4(1.37) \mathrm{b}$ & $84.1(1.08) \mathrm{d}$ & $2.38(1.19) \mathrm{c}$ & $41.9(10.8) \mathrm{ab}$ & $\mathrm{f}$ \\
\hline
\end{tabular}

${ }^{\mathrm{w}}$ Strains classified according to predicted amino acids present at positions 365 and 369 in Daf1p (Fig. 1).

x Values are means with standard error rate in brackets. Class values followed by the same letters in the same column are not significantly different at $P<0.05$.

${ }^{\mathrm{y}} \mathrm{EC}_{50}=$ concentration at which spore germination is inhibited by $50 \%$.

${ }^{\mathrm{z}}$ Fibrillose (f) or dense (d) margin when grown on malt-extract agar (MEA) plus $\mathrm{NaCl}$ (40 g/liter).

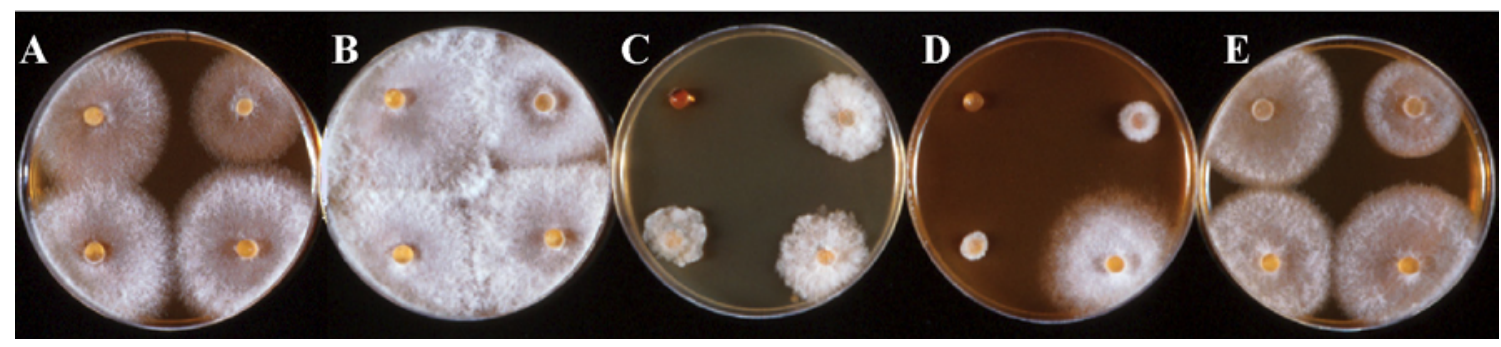

Fig. 2. Growth responses of selected strains of Botryotinia fuckeliana on A and B, malt-extract agar (MEA); C, MEA plus iprodione (5 mg/liter); D, MEA plus vinclozolin (100 mg/liter); and E, MEA plus $\mathrm{NaCl}$ (40 g/liter). Plates contain dicarboximide-sensitive A1 strain (top left) and three field-resistant strains REB6891 (class 1, top right), REB749-8 (class 2, bottom left), and REB954-1 (class 4, bottom right). Plates were inoculated as mycelial plugs and incubated for A, 2 days or $\mathbf{B}$ to $\mathbf{E}, 3$ days. 
Most laboratory mutants of Dafl showed abnormal response to high osmoticum $(6,22)$, but the responses of field strains were more equivocal $(3,5)$. In Figure 3 , the responses of all sequenced strains to iprodione and osmoticum $(\mathrm{NaCl})$ are plotted as a scatter diagram. Strains in classes 3 and 4 cluster together showing $\mathrm{EC}_{50}$ values for $\mathrm{NaCl}$ between 30 and $50 \mathrm{~g} /$ liter and $\mathrm{EC}_{50}$ values for iprodione between 1.5 and $3.0 \mathrm{mg} /$ liter. Class 2 isolates cluster in a group showing a similar range of $\mathrm{NaCl}$ responses but with lower iprodione responses. Class 1 strains did not cluster but showed a wide range of responses to both iprodione and $\mathrm{NaCl}$; indeed considering these strains as a group, there is a strong correlation between fungicide resistance and abnormal osmotic sensitivity (regression line, Fig. 3). Some, but not all, class 1 and class 3 strains showed a dense, as opposed to fibrillose, margin on osmotically amended medium (Table 2).

\section{DISCUSSION}

Our findings confirm reports that a change (mutation) from isoleucine to serine at aa position 365 in a putative osmosensing histidine kinase can confer dicarboximide fungicide resistance in field isolates $(22,25)$. In addition, we demonstrate that mutations to either asparagine or to arginine at this same position can also confer field resistance, confirming a preliminary report (22). The presence of serine at this position in strain SAS405, the original strain used to define Dafl (8), confirms the finding that Dafl is the gene encoding this histidine kinase (6).

Our findings demonstrate that classes 1, 2, and 3 are widely distributed around the world. Class 4 strains, however, have not been previously recognized. They were recovered from grapes in an experimental vineyard in Pukekohe, Auckland, a region where extensive cultivation of onions occurs. Onion growers began using iprodione and vinclozolin to control onion white rot (Sclerotium cepivorum) in 1979 , but changed to using procymidone in 1986 after enhanced soil degradation of both iprodione and vinclozolin became apparent (32). We propose that intensive dicarboximide fungicide usage especially of procymidone has inadvertently selected class 4 strains in the nontarget $B$. fuckeliana population.

New Zealand is the only place where all four field resistance classes have been found to date. Dicarboximide-resistant strains were recovered from the field in New Zealand in 1981 to 1982, soon after the introduction of the dicarboximide fungicides (3). Initially, most showed a slightly abnormal response to $\mathrm{NaCl}$ osmoticum, evidenced by a dense (abnormal), as opposed to the fibrillose (normal), margin characteristic of sensitive strains, and showed slightly less radial growth on $\mathrm{NaCl}$-amended medium $(3,4)$. Subsequently, resistant strains with a fibrillose margin became more common (4). Genetic crosses indicated that both these morphological phenotypes segregated $1: 1$ in crosses to SAS405 (5), and it was concluded that these two phenotypes were determined by different alleles of the Dafl locus, DaflLR and
Daf1UR (5). Based on these earlier findings, class 1 strains REB689-1 and REB705-1, as well as strain SAS405, carry Daf1LR alleles, and class 2 strains REB699-1 and REB749-8 carry DaflUR alleles, suggesting a direct correlation between these classifications. However, in the present study, some class 1 strains did not show the dense margin previously identified as being diagnostic for DaflLR strains (Table 2). We propose that these strains carry additional mutations that modulate the phenotype leading to a fibrillose, rather than dense, colony margin on $\mathrm{NaCl}$ medium. The existence of a modifier gene reducing the abnormal osmotic sensitivity of a laboratory-induced dicarboximide-resistance gene (os-5) has been demonstrated in N. crassa (14). Furthermore, it is possible that such modifying genes could include those associated with uptake of diverse fungicides such as ABC transporters (16), a proposal supported by the negative correlation between iprodione and osmotic responses for class 1 strains (Fig. 3). These findings mean it is not possible to allocate DafILR and DafIUR genotypes based only on growth phenotype, and we propose that all class 1 , class 2 , and class 3 strains be referred to as DafLR strains (carrying DaflLR alleles), while recognizing that different DaflLR alleles may give slightly different phenotypes. The distinct, highly vinclozolin-resistant class 4 strains can be robustly distinguished, and we propose they be referred to as DafVR (vinclozolin-resistant) strains, with genotype DaflVR. To date, two phenotypic classes have been recognized amongst laboratory-derived strains, DafHR showing high-level dicarboximide resistance coupled with high sensitivity to osmoticum, and DafLO showing low-level dicarboximide

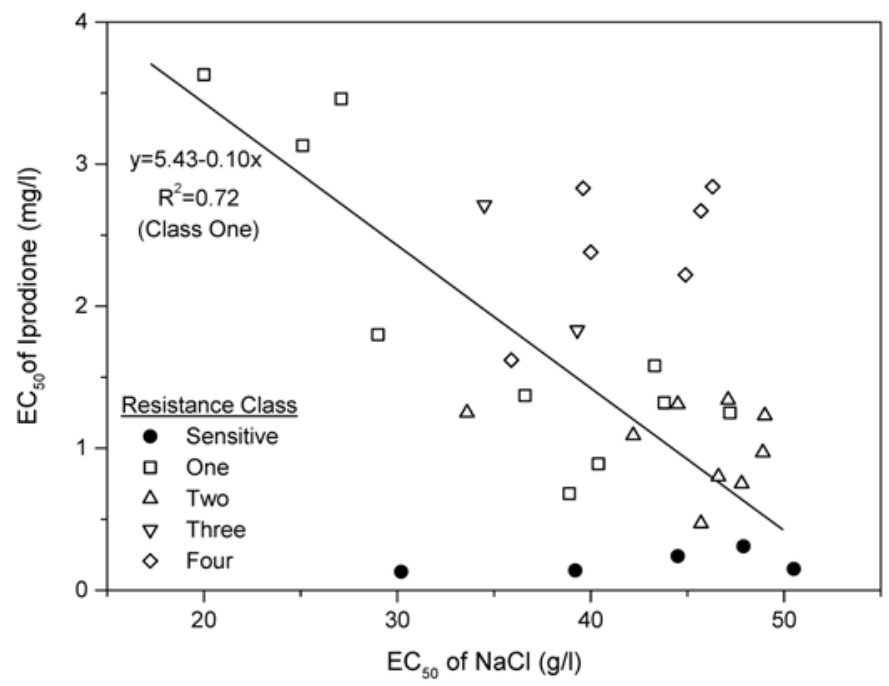

Fig. 3. Responses of strains of Botryotinia fuckeliana to iprodione and $\mathrm{NaCl}$ depicted in a scatter diagram. The different symbols correspond to different classes of resistance strains. The line indicates the regression line fitted to class 1 strains.

TABLE 3. Crosses between selected dicarboximide-sensitive strain and dicarboximide-resistant strains of Botryotinia fuckeliana

\begin{tabular}{|c|c|c|c|c|c|c|c|c|}
\hline \multirow[b]{2}{*}{ Cross no. } & \multicolumn{2}{|c|}{ Parents ${ }^{\mathrm{x}}$} & \multirow[b]{2}{*}{$\begin{array}{l}\text { Resistance } \\
\text { class }^{y}\end{array}$} & \multicolumn{5}{|c|}{ Progeny genotype (number of ascospores) } \\
\hline & $\begin{array}{l}\text { Sclerotial } \\
\text { parent }\end{array}$ & $\begin{array}{c}\text { Fertilizing } \\
\text { parent }\end{array}$ & & Total & $\begin{array}{l}\text { Sclerotial } \\
\text { parent }\end{array}$ & $\begin{array}{c}\text { Fertilizing } \\
\text { parent }\end{array}$ & $\begin{array}{c}\text { Recombinant } 1 \\
(M b c 1 H R-D a f 1 V R)\end{array}$ & $\begin{array}{l}\text { Recombinant } 2 \\
(M b c 1 S-D a f 1 L R)\end{array}$ \\
\hline 1 & $\begin{array}{l}\text { REB702-1 } \\
\text { (DaflS) }\end{array}$ & $\begin{array}{c}\text { REB909-51 } \\
\text { (DaflVR) }\end{array}$ & $s \times 4$ & 34 & 18 & 16 & - & - \\
\hline 2 & $\begin{array}{c}\text { REB702-1 } \\
(\text { DaflS })\end{array}$ & $\begin{array}{c}\text { REB909-56 } \\
\text { (DaflVR) }\end{array}$ & $\mathrm{s} \times 4$ & 35 & 16 & 19 & - & - \\
\hline 3 & $\begin{array}{c}\text { REB689-1 } \\
\text { (DaflLR-MbclHR) }\end{array}$ & $\begin{array}{c}\text { REB909-56 } \\
(\text { DaflVR-MbclS) }\end{array}$ & $1 \times 4$ & 100 & 34 & 41 & $15^{z}$ & $10^{\mathrm{z}}$ \\
\hline
\end{tabular}

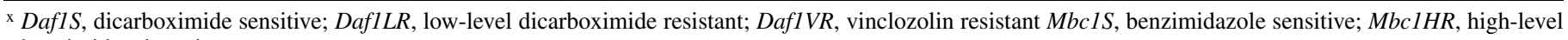
benzimidazole resistant.

${ }^{y}$ Strains classified according to predicted amino acids present at positions 365 and 369 in Daflp (Fig. 1).

${ }^{\mathrm{z}}$ Recombination between Dafl and $M b c 1=25 \%$ ( $\chi^{2}$ for independent assortment $=26.5, P<0.01$ ).
} 
resistance coupled with high osmotic sensitivity (6). Resistant strains with these characteristics have not, however, been found in the field.

All mutations in laboratory and field resistant strains identified so far occur in the aa repeat region of the enzyme in B. fuckeliana $(6,22)$, as do laboratory mutants in the model fungus $N$. crassa (13), supporting our suggestion that dicarboximide fungicides specifically bind to the aa repeat region (6). The change at aa position 365 from a hydrophobic (isoleucine) to a hydrophilic residue (serine in class 1 and class 4, asparagine in class 2, or arginine in class 3) presumably results in decreased hydrophobicity in the region of this residue, perhaps affecting fungicide binding directly. The additional change from glutamine to proline shown by class 4 strains is likely to have a significant effect on the polypeptide backbone in the vicinity of position 369 .

There have been numerous reports of variation in the responses of field strains to dicarboximide fungicides, indicating the existence of discrete subgroups of relatively low-level resistant strains in regions other than New Zealand $(11,19,21,34)$, suggesting the New Zealand situation is representative of the situation elsewhere.

It has been widely observed that the frequency of dicarboximide strains tends to decrease in the absence of dicarboximide applications $(12,20,24,26)$. Field resistant strains as a group do not consistently differ from sensitive strains in growth rate and sporulation on normal laboratory media although some DafLR strains show abnormal osmotic sensitivity (4,20,24). However, near-isogenic strains carrying Dafl (allele SAS405) in two different genetic backgrounds consistently showed that this allele is associated with reduced growth and abnormal osmotic sensitivity on various media (28). Sclerotia of resistant strains showed reduced survival ability under warm dry conditions (29), although only a few isolates were tested. Pathogenicity tests have usually indicated that field resistant strains are highly pathogenic although they may be less virulent than sensitive strains $(4,12,15$, 18 ), and dual inoculation experiments suggest they are usually less competitive $(4,20)$.

The DNA sequence data and physiological tests presented here coupled with field observations allow us to propose a scenario for the evolution of dicarboximide resistance in B. fuckeliana (Fig. $4)$. There is no evidence for the existence of dicarboximide-resis- tant strains in the field prior to introduction of these fungicides in the late 1970 s and early 1980 s $(3,21)$. It is reasonable to propose that both aa polymorphism groups 1 and 2 recognized here were present in the population, and that within these groups, occasional silent nucleotide polymorphisms were also present. Considering the aa repeat region, it is reasonable to suggest that both class 1 and class 2 strains arose by single step mutations from sensitive ancestors, either via transition T1214G (class 1) or transversion T1214A (class 2). The preponderance of resistant strains showing dense margins in New Zealand in 1981 to 1982 (3) suggests that class 1 strains appeared first. In contrast, it is reasonable to propose that both class 3 and class 4 strains also arose by single step mutations but in these instances from class 1 dicarboximide-resistant ancestors either via transversion A1213C (class 3) or transversion A1226C (class 4). This is consistent with the relatively infrequent occurrence and, at least in the case of class 4 strains, restricted geographic distribution of these two classes. The proposal that at least three ancestral sensitive strains are needed to generate the diversity of resistant strains found in the field (Fig. 4) suggests that mutations to resistance have arisen independently on at least three occasions.

Our findings allow us to make two general conclusions about development of fungicide resistance in the field. First, it is apparent that different mutations in the same gene can confer resistance. The finding that spontaneous mutations conferring resistance in laboratory strains $(6,22)$ have not yet been found in the field suggests that field conditions exert powerful selection, excluding resistant strains in which resistance is coupled with low fitness. Second, the identification of classes 3 and 4 implies that continued selection pressure in the field acting on "first generation" resistant strains can generate "second generation" strains of increased fitness and resistance. This latter finding has the practical implication of supporting recommendations to minimize applications of selective fungicides even when initial surveys following launching of a new fungicide suggest that changes in strain sensitivity are unimportant in terms of field control. Furthermore, our findings with the class 4 strains raises the complex issue of spray effects on nontarget pathogens and suggests that intensive use of selective fungicides on pathogens apparently not at risk from developing fungicide resistance may nevertheless impact those that are.

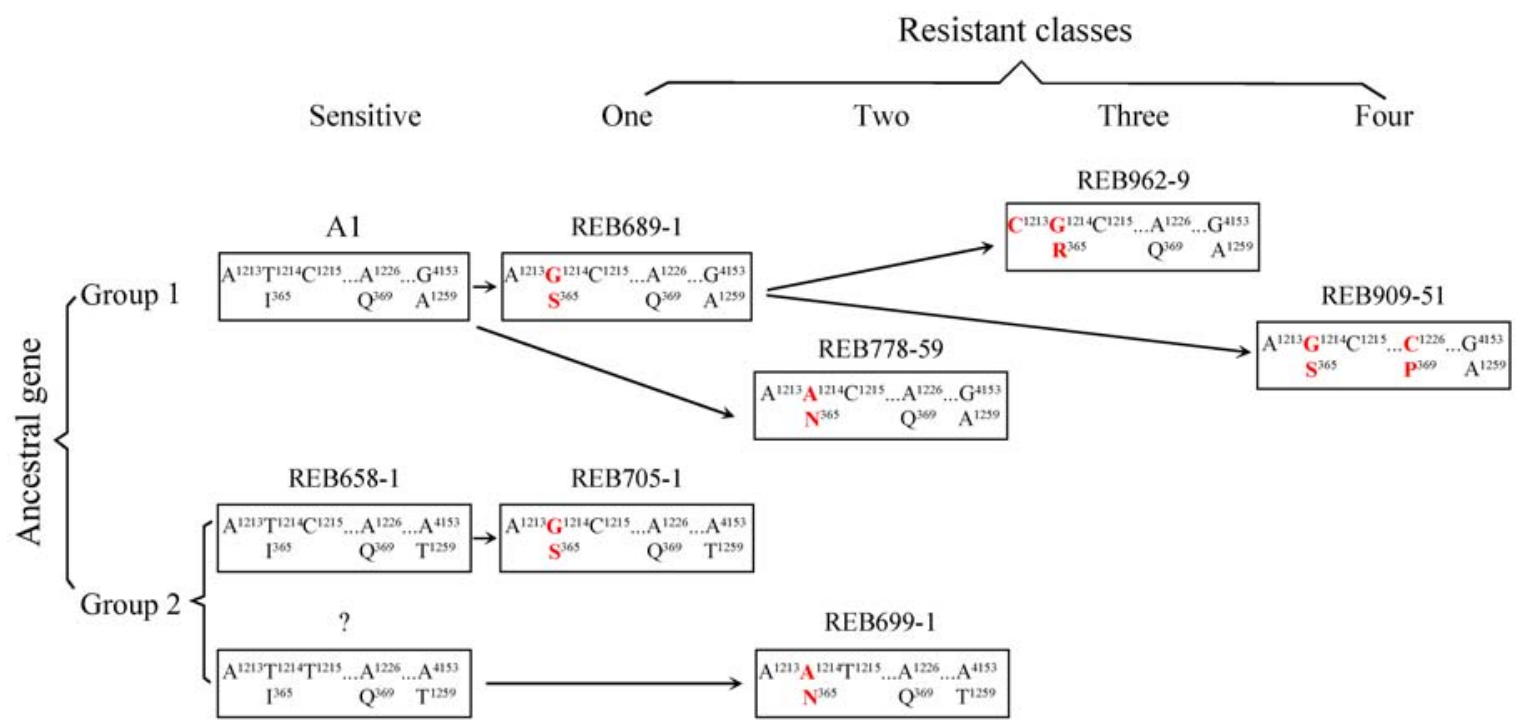

Fig. 4. Hypothesis of the evolution of the Dafl osmosensing histidine kinase in field strains of Botryotinia fuckeliana. Two broad groups of ancestral sensitive strains are recognized, based on the presence of alanine (group 1) or threonine (group 2) at amino acid (aa) position 1259. The boxes present the variable nucleotide (top line) and aa (bottom line) positions in Daf1 gene, and arrows indicate putative single step mutations required to produce the various dicarboximide-resistant classes. Representative strains are listed above the boxes. The question mark indicates a postulated subgroup of sensitive strains that has not yet been detected in the field. 


\section{ACKNOWLEDGMENTS}

We thank N. De Silva for statistical analyses and D. R. Greenwood and E. H. A. Rikkerink for helpful discussions. The strains from Europe and Israel were supplied by F. Faretra and strains from the United States were supplied by A. B. A. M. Baudoin. This research was funded by an AGMARDT (The Agricultural and Marketing Research and Development Trust of New Zealand) postdoctoral fellowship to W. Cui and the New Zealand Foundation for Research Science and Technology (contract COX0207).

\section{LITERATURE CITED}

1. Alex, L. A., Borkovich, K. A., and Simon, M. I. 1996. Hyphal development in Neurospora crassa: Involvement of a two-component histidine kinase. Proc. Natl. Acad. Sci. USA 93:3416-3421.

2. Beever, R. E. 1983. Osmotic sensitivity of fungal variants resistant to dicarboximide fungicides. Trans. Br. Mycol. Soc. 80:327-331.

3. Beever, R. E., and Brien, H. M. R. 1983. A survey of resistance to the dicarboximide fungicides in Botrytis cinerea. N.Z. J. Agric. Res. 26:391400.

4. Beever, R. E., Laracy, E. P., and Pak, H. A. 1989. Strains of Botrytis cinerea resistant to dicarboximide and benzimidazole fungicides in New Zealand vineyards. Plant Pathol. 38:427-437.

5. Beever, R. E., and Parkes, S. L. 1993. Mating behaviour and genetics of fungicide resistance of Botrytis cinerea in New Zealand. N.Z. J. Crop Hortic. Sci. 21:303-310.

6. Cui, W., Beever, R. E., Parkes, S. L., Weeds, P. L., and Templeton, M. D. 2002. An osmosensing histidine kinase mediates dicarboximide fungicide resistance in Botryotinia fuckeliana (Botrytis cinerea). Fungal Genet. Biol. 36:187-198.

7. Delp, C. J., ed. 1988. Fungicide Resistance in North America. The American Phytopathological Society, St. Paul, MN.

8. Faretra, F., and Pollastro, S. 1991. Genetic basis of resistance to benzimidazole and dicarboximide fungicides in Botryotinia fuckeliana (Botrytis cinerea). Mycol. Res. 95:943-951.

9. Faretra, F., and Pollastro, S. 1993. Isolation, characterization and genetic analysis of laboratory mutants of Botryotinia fuckeliana resistant to the phenylpyrrole fungicide CGA 173506. Mycol. Res. 97:620-624.

10. Faretra, F., and Pollastro, S. 1993. Genetics of sexual compatibility and resistance to benzimidazole and dicarboximide fungicides in isolates of Botryotinia fuckeliana (Botrytis cinerea) from nine countries. Plant Pathol. 42:48-57.

11. Fourie, P. H., and Holz, G. 1998. Frequency of dicarboximide resistant strains of Botrytis cinerea in South African table grape vineyards and influence of spray schedules on resistant sub-populations. S. Afr. J. Enol. Vitic. 19:3-9.

12. Fourie, P. H., and Holz, G. 2003. Fitness on grape berries of Botrytis cinerea isolates belonging to different dicarboximide sensitivity classes. S. Afr. J. Enol. Vitic. 24:1-10.

13. Fujimura, M., Ochiai, N., Ichiishi, A., Usami, R., Horikoshi, K., and Yamaguchi, I. 2000. Fungicide resistance and osmotic stress sensitivity in os mutants of Neurospora crassa. Pestic. Biochem. Physiol. 67:125-133.

14. Grindle, M., and Dolderson, G. H. 1986. Effects of a modifier gene on the phenotype of a dicarboximide-resistant mutant of Neurospora crassa. Trans. Br. Mycol. Soc. 87:457-487.

15. Gullino, M. L., Romano, M. L., and Garibaldi, A. 1982. Characterization of dicarboximide-resistant strains of Botrytis cinerea Pers, naturally occurring in Italy. Med. Fac. Landbouww. Rijksuniv. Gent. 47:781-791.

16. Hayashi, K., Schoonbeek, H.-J., Sugiura, H., and De Waard, M. A. 2001. Multidrug resistance in Botrytis cinerea associated with decreased accumulation of the azole fungicide oxpoconazole and increased transcrip- tion of the ABC transporter gene BcatrD. Pestic. Biochem. Physiol. 70:168-179.

17. Heaney, S., Slawson, D., Hollomon, D. W., Smith, M., Russell, P., and Parry, D. W., eds. 1994. Fungicide resistance. BCPC Monograph No. 60. The British Crop Protection Council, Farnham, UK.

18. Katan, T. 1982. Resistance to 3,5-dichlorophenyl-cyclic imide ('dicarboximide') fungicides in the grey mould pathogen Botrytis cinerea on protected crops. Plant Pathol. 31:133-141.

19. Latorre, B. A., Flores, V., Sara, A. M., and Roco, A. 1994. Dicarboximide-resistant isolates of Botrytis cinerea from table grape in Chile: Survey and characterization. Plant Dis. 78:990-994.

20. Leroux, P., and Clerjeau, M. 1985. Resistance of Botrytis cinerea Pers. and Plasmopara viticola (Berk. \& Curt.) Ber1. and de Toni to fungicides in French vineyards. Crop Prot. 4:137-160.

21. Leroux, P., Chapeland, F., Desbrosses, D., and Gredt, M. 1999. Patterns of cross-resistance to fungicides in Botryotinia fuckeliana (Botrytis cinerea) isolates from French vineyards. Crop Prot. 18:687-697.

22. Leroux, P., Fritz, R., Debieu, D., Albertini, C., Lanen, C., Bach, J., Gredt, M., and Chapeland, F. 2002. Mechanisms of resistance to fungicides in field strains of Botrytis cinerea. Pest Manage. Sci. 58:876-888.

23. Lyr, H., Russell, P. E., Dehne, H.-W., and Sisler, H. D., eds. 1999. Modern Fungicides and Antifungal Compounds II. Intercept Limited, Andover, UK.

24. Northover, J. 1988. Persistence of dicarboximide-resistant Botrytis cinerea in Ontario vineyards. Can. J. Plant Pathol. 10:123-132.

25. Oshima, M., Fujimura, M., Banno, S., Hashimoto, C., Motoyama, T., Ichiishi, A., and Yamaguchi, I. 2002. A point mutation in the two-component histidine kinase $B C O S-1$ gene confers dicarboximide resistance in field isolates of Botrytis cinerea. Phytopathology 92:75-80.

26. Pak, H. A., Beever, R. E., and Laracy, E. P. 1990. Population dynamics of dicarboximide-resistant strains of Botrytis cinerea on grapevine in New Zealand. Plant Pathol. 39:501-509.

27. Perkins, D. D. 1977. Details for preparing silica gel stocks. Neurospora Newsl. 24:16-17.

28. Pollastro, S., Faretra, F., Santomauro, A., Miazzi, M., and Natale, P. 1996. Studies on pleiotropic effects of mating type, benzimidazole-resistance and dicarboximide-resistance genes in near-isogenic strains of Botryotinia fuckeliana (Botrytis cinerea). Phytopathol. Mediterr. 35:48-57.

29. Raposo, R., Gomez, V., Urrutia, T., and Melgarejo, P. 2000. Fitness of Botrytis cinerea associated with dicarboximide resistance. Phytopathology 90:1246-1249.

30. Sambrook, J., Fritsch, E. F., and Maniatis, T. 1989. Molecular Cloning: A Laboratory Manual. 2nd ed. Cold Spring Harbor Laboratory, Cold Spring Harbor, NY.

31. Schumacher, M. M., Enderlin, C. S., and Selitrennikoff, C. P. 1997. The osmotic-1 locus of Neurospora crassa encodes a putative histidine kinase similar to osmosensors of bacteria and yeast. Curr. Microbiol. 34:340-347.

32. Slade, E. A., and Fullerton, R. A. 1992. Degradation of the dicarboximide fungicides iprodione, vinclozolin and procymidone in Patumahoe clay loam soil, New Zealand. Pestic. Sci. 35:95-100.

33. Staden, R., Beal, K. F., and Bonfield, J. F. 1998. The Staden package. Pages 115-130 in: Computer Methods in Molecular Biology. S. Misener and S. Krawetz, eds. The Humana Press, Totowa, NJ.

34. Stehmann, C., and De Waard, M. A. 1996. Sensitivity of populations of Botrytis cinerea to triazoles, benomyl and vinclozolin. Eur. J. Plant Pathol. 102:171-180.

35. Vogel, H. J. 1964. Distribution of lysine pathways among fungi: Evolutionary implications. Am. Nat. 98:435-446.

36. Weeds, P. L., Beever, R. E., and Long, P. G. 1998. New genetic markers for Botrytis cinerea (Botryotinia fuckeliana). Mycol. Res. 102:791-800.

37. Yourman, L. F., and Jeffers, S. N. 1999. Resistance to benzimidazole and dicarboximide fungicides in greenhouse isolates of Botrytis cinerea. Plant Dis. 83:569-575. 